\title{
Cognitive Impairment among Persons of Rural Background Living with Human Immunodeficiency Virus Infection on Antiretroviral Therapy: A Study from a Tertiary Care Centre of North India
}

Sir,

Human immunodeficiency virus (HIV) infection is often accompanied by progressive neuropsychiatric manifestations varying between asymptomatic neurocognitive impairment, mood and personality disorders, psychosis, mild cognitive-motor disorder, and HIV-associated dementia (HAD). ${ }^{[1,2]}$ Since it adversely affects adherence to medications, interact socially or ability to work, and employability, early recognition and management of individuals with HAD are important for improving quality of their life. ${ }^{[3,4]}$ However, it remains understudied despite a significant prevalence of HIV/AIDS-affected Indian populations. . $^{[-7]}$

We studied 356 (male:female 154:202) HIV/AIDS-affected persons (old and new) aged 10-79 (mean $\pm \mathrm{SD}=39.67 \pm 9.88)$ years between July 2015 and June 2016 presenting in the dermatology outpatient clinic and institutional antiretroviral 


\begin{tabular}{|c|c|}
\hline Maximum score & BMSE \\
\hline 5 & What is the time of day? day, date, month, and season \\
\hline 5 & Where are we now: country/state/district/district/block/panchayat \\
\hline 3 & $\begin{array}{l}\text { The examiner names three unrelated objects in native (Bharmouri) language clearly and slowly, then asks the } \\
\text { patient to name all three of them. The patient's response is used for scoring. The examiner repeats them until } \\
\text { patient learns all of them, if possible. Number of trials: }\end{array}$ \\
\hline \multirow[t]{2}{*}{5} & $\begin{array}{l}\text { We constructed a story for the subtraction task: "You went to a grocer with a fifty rupees note to make a } \\
\text { purchase of seven rupees. After paying him how much will be left with you? In the next morning you went again } \\
\text { to purchase the same item, how much will be left with you?" The first five consecutive responses are scored }\end{array}$ \\
\hline & $\begin{array}{l}\text { World backward. Since most of the sample is illiterate, spelling (either forward or backward) is not an option. } \\
\text { We ask subjects to name the months in Hindu calendar backward, starting from the current month. Responses } \\
\text { were scored for the } 5 \text { months named, not including the current month. This was thought as closest possible to } \\
\text { "world backward" option in capturing attention of the subjects }\end{array}$ \\
\hline 3 & Earlier, I told you the names of three things. Can you tell me what those were? \\
\hline 2 & Show the patient two simple objects, such as a wristwatch and a pencil, and ask the patient to name them \\
\hline 1 & Repeat the phrase with: now, when, then as focus \\
\hline 3 & $\begin{array}{l}\text { Take the paper in your right hand, fold it in half, and put it on the floor (the examiner gives the patient a piece of } \\
\text { blank paper) }\end{array}$ \\
\hline 1 & $\begin{array}{l}\text { The examiner says, "just see what I am doing and repeat the same" and then closes his own eyes for } 3 \mathrm{~s} \text { (follow } \\
\text { example) and later examiner observes the subject (see and follow command) }\end{array}$ \\
\hline 1 & A meaningful sentence generation in response to the question by the examiner \\
\hline 1 & $\begin{array}{l}\text { Please copy this picture (the examiner gives the patient a blank piece of paper and asks him/her to draw the } \\
\text { symbol below) }\end{array}$ \\
\hline 30 & Total \\
\hline
\end{tabular}

Interpretation of score: (1) Maximum score = 30, (2) Score $\geq 24=$ Normal, (3) Score between 18 and $23=$ Mild dementia (4) Score $<18=$ Moderate to severe dementia. BMSE: Bharmour Mental State Examination

therapy (ART) center. Their sociodemographic details, CD4 counts, and presence of any other illness were recorded from individual's highly active ART (HAART) records and clinical examination. All enrolled subjects completed a predesigned questionnaire with investigators' help in their native language [Table 1]. This pretested questionnaire to suit Indian patients is structured for assessing the dementia status of HIV/AIDS-affected persons using Bharmour Mental State Examination (BMSE) scale. ${ }^{[8]}$

The clinicoepidemiologic profile of the study population [Table 2] was similar as reported previously ${ }^{[9]}$ and comprised majority, 235 (66\%) in 31-45 years age group. The $336(94.4 \%)$ ruralites made the majority and $206(56.9 \%)$ persons were either school dropouts, illiterate, or under matric. Most, 121 (34\%), individuals were drivers, staying-alone laborers, and self-employed among males and 196 (55\%) women were homemakers. The $22(6.2 \%)$ children/adolescents (16 boys, 6 girls) aged 10-19 years were students. The mode of infection was heterosexual in $335(94.1 \%)$ individuals. The majority, $340(95.5 \%)$ persons, were in WHO stage-1 of HIV disease. ${ }^{[10]}$ All $(100 \%)$ were on regular HAART for 1 month to 9 (mean 3.5) years and CD4 counts ranged from 100 to 350 cells $/ \mathrm{mm}^{3}$ in $142(39.9 \%),>500$ cells $/ \mathrm{mm}^{3}$ in $136(38.2 \%)$, and $<100$ cells $/ \mathrm{mm}^{3}$ in $78(21.9 \%)$ individuals, respectively.

Only $3(0.8 \%)$ persons were identified having mild dementia/neurocognitive impairment on BMSE scale; a 10-year-old school-going boy (Score: 22), a 38-year-old self-employed man (Score: 22), and 31-year-old woman (Score: 23). They had WHO clinical stage-1 of the disease, were under matric, on regular HAART (tenofovir, efavirenz, lamivudine) for 6 months, 4 years, and 5 years, respectively, which was started a month after clinical diagnosis. They had CD4 counts of 173,190 , and 179 cells $/ \mathrm{mm}^{3}$, respectively.

HAD, a phenotype of HIV-encephalitis, earlier known as AIDS dementia complex (ADC), is attributed to the virus-infected brain macrophages and activated microglia in the central nervous system. HIV-associated neurocognitive disorder is the new definition for ADC and considered AIDS-defining illness. It was not uncommon having an estimated incidence of $10 \%$ before the introduction of HAART in 1996 but has decreased approximately by $50 \%$, since then with an estimated prevalence of $21 \%-80 \%$ now..$^{[1,11]}$ Paradoxically, an increased prevalence of mild forms is being recognized more often than before. ${ }^{[2,12]}$ However, the overall incidence and prevalence rates of HAD in the post-HAART era vary greatly by geography, treatment, and risk factors studied. ${ }^{[13]}$ Old aged HIV + individuals are definitely at higher risk for HAD than HIV-seronegative individuals. ${ }^{[14,15]}$ High viral load during early stage, female gender, family history of dementia, depression, low educational level, unemployment, low CD4 counts (nadir CD 4 count 50 cells $/ \mathrm{mm}^{3}$ ), anemia, systemic symptoms, and intravenous drug abuse are other identified risk factors for HAD in studies but included no Indian populations..$^{[2,11,16-19]}$ Good education suggests a cognitive reserve and mind's resiliency to neuropathological damage while HIV/AIDS-affected individuals with lower cognitive reserve have demonstrated worse neuropsychometric performance. ${ }^{[19]}$ This is also evident in our $3(0.8 \%)$ patients with signs of mild HAD having low education status, the only identified risk factor in them. However, we did not study HIV viremia in them. 
Table 2: Baseline characteristics of patients

\begin{tabular}{|c|c|c|}
\hline Baseline characteristics & $\begin{array}{l}\text { Total number of patients } \\
\text { studied, } n=356(\%)\end{array}$ & $\begin{array}{l}\text { Patients with cognitive } \\
\text { impairment }(n=3)\end{array}$ \\
\hline \multicolumn{3}{|l|}{ Gender } \\
\hline Men & $154(43.3)$ & 2 \\
\hline Women & $202(56.7)$ & 1 \\
\hline Men:women & $1: 1.3$ & - \\
\hline \multicolumn{3}{|l|}{ Age (years) } \\
\hline Range (mean $\pm \mathrm{SD}$ ) & $10-79(39.67 \pm 9.88)$ & \\
\hline$<15$ & $6(1.7)$ & 1 \\
\hline $16-30$ & $37(10.4)$ & - \\
\hline $31-45$ & $235(66.0)$ & 2 \\
\hline $46-60$ & $72(20.2)$ & - \\
\hline$>60$ & $6(1.7)$ & - \\
\hline \multicolumn{3}{|l|}{ Social background } \\
\hline Married & $274(76.9)$ & 2 \\
\hline Unmarried & $24(6.7)$ & 1 \\
\hline Widowed & $55(15.4)$ & - \\
\hline Divorced & $3(0.8)$ & - \\
\hline Rural & $336(94.4)$ & - \\
\hline Urban & $20(5.6)$ & - \\
\hline \multicolumn{3}{|l|}{ Education status } \\
\hline Under $10^{\text {th }}$ standard/school drop outs/illiterates & $206(56.9)$ & 3 \\
\hline $10^{\text {th }}$ standard or more & $150(42.2)$ & - \\
\hline \multicolumn{3}{|l|}{ Occupation } \\
\hline \multicolumn{3}{|l|}{ Men } \\
\hline Drivers & $72(20.2)$ & - \\
\hline Laborers & $20(5.6)$ & - \\
\hline Self-employed & $29(8.1)$ & 1 \\
\hline Government employed & $15(4.2)$ & - \\
\hline Defense personnel & $2(0.6)$ & - \\
\hline Students & $16(5.5)$ & 1 \\
\hline \multicolumn{3}{|l|}{ Women } \\
\hline Homemakers & $196(55.0)$ & 1 \\
\hline Students & $6(1.7)$ & -- \\
\hline \multicolumn{3}{|l|}{ Mode of disease acquisition } \\
\hline Heterosexual & $335(94.1)$ & \\
\hline Mother to child (vertical) & $17(4.8)$ & - \\
\hline Blood transfusion & $3(0.8)$ & - \\
\hline Injections & $1(0.3)$ & - \\
\hline \multicolumn{3}{|l|}{ CD4 cell counts, $n=356\left(\right.$ cells $\left./ \mathrm{mm}^{3}\right)$} \\
\hline$>500$ & $86(24.2)$ & - \\
\hline$>350-500$ & $50(14.0)$ & - \\
\hline$>200-350$ & $48(13.5)$ & 1 \\
\hline \multicolumn{3}{|l|}{ Range 6-1254 (cells $\left./ \mathrm{mm}^{3}\right)$} \\
\hline$>100-200$ & $94(26.4)$ & 2 \\
\hline$<100$ & $78(21.9)$ & - \\
\hline \multicolumn{3}{|l|}{ Clinical stage (WHO 2007) ${ }^{[9]}$} \\
\hline Stage 1 & $340(95.5)$ & 3 \\
\hline Stage 2 & $12(3.4)$ & - \\
\hline Stage 3 & $4(1.1)$ & - \\
\hline Stage 4 & 0 & - \\
\hline \multicolumn{3}{|l|}{ Time interval between diagnosis and initiating ART } \\
\hline Range (mean) & 1 day to 13.5 years (383.13 days) & $0-10$ days \\
\hline \multicolumn{3}{|l|}{ Duration of ART } \\
\hline Range (mean) & 1 month to 9 years ( 3.5 years) & 1 month to 2 years \\
\hline
\end{tabular}

ART: Antiretroviral therapy, WHO: World Health Organization, SD: Standard deviation

Although several screening tools have been used to identify cognitively impaired individuals in HIV outpatient clinics, the International HIV Dementia Scale remains popular internationally. ${ }^{[14,15,20-22]}$ Indian studies have also used similar scales; $;^{[6,7]}$ however, being in English, it remains under-evaluated being poorly comprehensible by Indian patients. The BMSE scale in native language used by us was convenient and easily comprehended by studied subjects. 
Despite small number of subjects, lack of HIV-seronegative controls, and no viral load studies, HAD/neurocognitive impairment does not seem uncommon even among individuals on HAART. However, our results may not represent other HIV/AIDS-affected populations for being limited period, single-center, cross-sectional study. Nevertheless, an early screening for neurocognitive impairment using a formal neuropsychometric battery and identification of risk factors in Indian subjects will help in planning of comprehensive health care envisaged in Phase-IV NACP for at-risk patients.

\section{Acknowledgments}

The help extended by all the staff members at ART Centre, Dr. R. P. Government Medical College, Kangra (Tanda), Himachal Pradesh, is gratefully acknowledged.

\section{Financial support and sponsorship}

Nil.

\section{Conflicts of interest}

There are no conflicts of interest.

Vikram K. Mahajan, Sunil Rainal, Sakshi Kohli, Sarita Gupta, Shailja Sharma ${ }^{1}$

Departments of Dermatology, Venereology and Leprosy and ${ }^{1}$ Community Medicine, Dr. R. P. Government Medical College, Kangra, Tanda, Himachal Pradesh, India

Address for correspondence: Dr. Vikram K. Mahajan, Department of Dermatology, Venereology and Leprosy, Dr. R. P. Government Medical College, Kangra, Tanda - 176001 , Himachal Pradesh, India. E-mail: vkm1@rediffmail.com

\section{REFERENCES}

1. Xia C, Luo D, Yu X, Jiang S, Liu S. HIV-associated dementia in the era of highly active antiretroviral therapy (HAART). Microbes Infect 2011;13:419-25.

2. Silva MM. Neurologic complications of HIV in the HAART era: Where are we? Braz J Infect Dis 2012;16:373-8.

3. Hinkin CH, Castellon SA, Durvasula RS, Hardy DJ, Lam MN, Mason KI, et al. Medication adherence among HIV+ adults: Effects of cognitive dysfunction and regimen complexity. Neurology 2002;59:1944-50.

4. Hinkin CH, Hardy DJ, Mason KI, Castellon SA, Durvasula RS, Lam MN, et al. Medication adherence in HIV-infected adults: Effect of patient age, cognitive status, and substance abuse. AIDS 2004;18 Suppl 1:S19-25.

5. NACO Annual Report 2012-2013. Department of AIDS Control. Ministry of Health and Family Welfare, New Delhi, India; 2013.

6. Muniyandi K, Venkatesan J, Arutselvi T, Jayaseelan V. Study to assess the prevalence, nature and extent of cognitive impairment in people living with AIDS. Indian J Psychiatry 2012;54:149-53.

7. Saini S, Barar KV. Assessment of neurocognitive functions in HIV/AIDS patients on HAART using the international HIV dementia scale. Int J Nutr Pharmacol Neurol Dis 2014;4:252-5.

8. Raina SK, Raina S, Chander V, Grover A, Singh S, Bhardwaj A. Development of a cognitive screening instrument for tribal elderly population of Himalayan region in Northern India. J Neurosci Rural Pract 2013;4:147-53.

9. Gupta M, Mahajan VK, Chauhan PS, Mehta KS, Rawat R, Shiny TN. Knowledge, attitude, and perception of disease among persons living with human immunodeficiency virus/acquired immuno deficiency syndrome: A study from a tertiary care center in North India. Indian J Sex Transm Dis 2016;37:173-7.
10. World Health Organization. WHO Case Definition of HIV for Surveillance and Revised Clinical Staging and Immunological Classification of HIV-Related Disease in Adults and Children. Geneva, World Health Organization; 2007. Available from: http://www.who.int/hiv/pub/guidelines/HIVstaging150307.pdf. [Last accessed on 2015 Jun 19].

11. Lekoubou A, Echouffo-Tcheugui JB, Kengne AP. Epidemiology of neurodegenerative diseases in Sub-Saharan Africa: A systematic review. BMC Public Health 2014;14:653.

12. Gelman BB, Lisinicchia JG, Morgello S, Masliah E, Commins D, Achim CL, et al. Neurovirological correlation with HIV-associated neurocognitive disorders and encephalitis in a HAART-era cohort. J Acquir Immune Defic Syndr 2013;62:487-95.

13. Cross S, Önen N, Gase A, Overton ET, Ances BM. Identifying risk factors for HIV-associated neurocognitive disorders using the international HIV dementia scale. J Neuroimmune Pharmacol 2013;8:1114-22.

14. Stern RA, Silva SG, Chaisson N, Evans DL. Influence of cognitive reserve on neuropsychological functioning in asymptomatic human immunodeficiency virus-1 infection. Arch Neurol 1996;53:148-53.

15. Valcour V, Paul R, Neuhaus J, Shikuma C. The effects of age and HIV on neuropsychological performance. J Int Neuropsychol Soc 2011; 17:190-5.

16. Kelly CM, van Oosterhout JJ, Ngwalo C, Stewart RC, Benjamin L, Robertson KR, et al. HIV associated neurocognitive disorders (HAND) in Malawian adults and effect on adherence to combination anti-retroviral therapy: A cross sectional study. PLoS One 2014;9:e98962.

17. Robertson K, Bayon C, Molina JM, McNamara P, Resch C, Muñoz-Moreno JA, et al. Screening for neurocognitive impairment, depression, and anxiety in HIV-infected patients in Western Europe and Canada. AIDS Care 2014;26:1555-61.

18. Stern Y, McDermott MP, Albert S, Palumbo D, Selnes OA, McArthur J, et al. Factors associated with incident human immunodeficiency virus-dementia. Arch Neurol 2001;58:473-9.

19. Ellis RJ, Badiee J, Vaida F, Letendre S, Heaton RK, Clifford D, et al. CD4 nadir is a predictor of HIV neurocognitive impairment in the era of combination antiretroviral therapy. AIDS 2011;25:1747-51.

20. Sacktor NC, Wong M, Nakasujja N, Skolasky RL, Selnes OA, Musisi S, et al. The international HIV dementia scale: A new rapid screening test for HIV dementia. AIDS 2005;19:1367-74.

21. Njamnshi AK, Bissek AC, Ongolo-Zogo P, Tabah EN, Lekoubou AZ, Yepnjio FN, et al. Risk factors for HIV-associated neurocognitive disorders (HAND) in Sub-Saharan Africa: The case of Yaoundé-Cameroon. J Neurol Sci 2009;285:149-53.

22. Joska JA, Westgarth-Taylor J, Hoare J, Thomas KG, Paul R, Myer L, et al. Validity of the international HIV dementia scale in South Africa. AIDS Patient Care STDS 2011;25:95-101.

This is an open access article distributed under the terms of the Creative Commons Attribution-NonCommercial-ShareAlike 3.0 License, which allows others to remix, tweak, and build upon the work non-commercially, as long as the author is credited and the new creations are licensed under the identical terms.

\begin{tabular}{|l|l|}
\hline \multicolumn{2}{|c|}{ Access this article online } \\
\hline Quick Response Code: & Website: \\
\hline
\end{tabular}

How to cite this article: Mahajan VK, Raina S, Kohli S, Gupta S, Sharma S. Cognitive impairment among persons of rural background living with human immunodeficiency virus infection on antiretroviral therapy: A study from a tertiary care centre of North India. J Neurosci Rural Pract 2016;7:S131-4. 